\title{
Bio-Interaction of Chlordane on Non-Target Organisms
}

\author{
Emrihan ÖZYURT11, Halit KIZILET2², Handan UYSAL ${ }^{1, *}$ \\ ${ }^{1}$ Biology Department, Science Faculty, Atatürk University, 25240, Erzurum, Turkey \\ ${ }^{2}$ Erzurum Regional Training and Research Hospital, Ministry of Health, Erzurum, Turkey
}

\begin{abstract}
Received: 25.04 .2018
Accepted: 01.06 .2018

Available online: 26.06 .2018

Published: 30.06 .2018

Abstract: In the present study, the effects of chlordane $\left(\mathrm{C}_{10} \mathrm{H}_{6} \mathrm{Cl}_{8}\right)$ from organochlorine insecticides on living organisms were investigated in vivo and in vitro. For this purpose, in vivo effects of the chlordane on the longevity of $q$ and $\delta$ populations of Drosophila melanogaster, which is one of the non-target organisms, were studied. It was observed that the longevity of both populations significantly decreased in chronic applications depending on the dose-time interaction. Furthermore, whether the chlordane was genotoxic and cytotoxic was also investigated via in vitro micronucleus (MN) test by using human peripheral blood culture. It was observed in lymphocyte cells that the frequency of micronucleus considerably increased depending on the increasing dose of chlordane whereas the nuclear division index (NDI) decreased.

Keywords: Drosophila melanogaster, chlordane, micronucleus, longevity

\section{Hedef Olmayan Organizmalarda Klordanın Biyo-Etkileşimi}

Özet: Sunulan çalışmada organoklorlu insektisitlerden klordanın $\left(\mathrm{C}_{10} \mathrm{H}_{6} \mathrm{Cl}_{8}\right)$ canlılar üzerindeki etkileri in vivo ve in vitro olarak incelenmiştir. Bu amaçla hedef olmayan organizmalardan birisi olan Drosophila melanogaster'in $q$ ve $\hat{o}$ popülasyonunda klordanın ömür uzunluğu üzerine etkileri in vivo olarak çalışılmıştır. Kronik olarak yapılan uygulamalarda doz-süre etkileşimine bağlı olarak her iki popülasyonda da ömür uzunluğunun önemli oranda kısaldığı gözlenmiştir. Ayrıca klordanın genotoksik ve sitotoksik olup olmadığı da insan periferik kan kültürü kullanılarak in vitro mikronükleus (MN) testi ile araştırılmıştır. Klordanın yine artan dozuna bağlı olarak lenfosit hücrelerinde mikronükleus frekansının önemli oranda arttığı, nükleer bölünme indeksinin ise (NBI) azaldığı gözlenmiştir.
\end{abstract}

Anahtar kelimeler: Drosophila melanogaster, klordan, mikronükleus, ömür uzunluğu

\section{Giriş}

İnsanlar yüzyıllardan beri çevreyi denetim altına alma çabası içinde olmuşlardır. Günümüzde yaşam standardını yükseltebilmek için yerleşime açık yerlerin artırılması amacıyla ekilebilir ve sulak alanlar geri dönüşümsüz olarak tahrip edilmiş ve edilmeye devam etmektedir. Ancak bu kez de hızla artan dünya nüfusunun besin ihtiyacının karşılanabilmesi için birim alandan daha fazla ürün alabilme çabaları, çevre üzerindeki olumsuz etkileri geometrik olarak artırmıştır (Güler ve Çobanoğlu, 1997). Özellikle ürünlerin miktarını artırmak için hem üretici firmaların hem de çiftçilerin toksik olduğunu/olabileceğini bilmesine rağmen en sık ve en kolay başvurulan yöntemlerden birisi hala pestisit kullanımı olup bu maddeler canlı sistemleri doğrudan veya dolaylı yollardan hissedilir biçimde etkilemektedir.

Pestisit, zararlı organizmalara karşı toksik ya da biyosidal etki gösteren madde ya da madde karışımlarının genel adıdır. Bu tip kimyasal maddeler hayvansal ve bitkisel organizmaları engellemek, kontrol altına almak, onların olası zararlı etkilerini azaltmak amaciyla kullanılırlar. Pestisitler, Dünya Sağlık Örgütü (WHO: World Health Organization) tarafından insan veya hayvan hastalıklarını taşıyan rahatsızlık verici canlılar dâhil olmak üzere gida, tarımsal ürün, ağaç ve orman ürünleri veya hayvan yemlerinin üretimi, işlenmesi, depolanması, taşınması veya satışı sırasında istenmeyen zararlı etkilere neden olabilecek canlıları kaçırtmak, öldürmek ya da kontrol etmek amacı ile kullanılan ya da hayvanların üzerinde veya içinde bulunan böcek, eklem bacaklı vb. zararlı canlıları kontrol etmek amacı ile virüsler dâhil olmak üzere mikroorganizmalar veya hayvanlara uygulanabilen herhangi bir madde ya da madde karışımları olarak tanımlanmaktadır (WHO, 2018).

Pestisit kavramı yeni bir kavram olmayıp tarihsel süreç içinde çeşitli maddeler bu amaçla kullanılmıştır. MÖ 1550 yılında Eski Misır'da yazılmış olan Ebers papirüslerinde $800^{\prime}$ den fazla reçetede zehir ve pestisit olarak kullanılan çeşitli bileşikler tanımlanmıştır. MÖ 2500 yılında kötü kokusu nedeni ile kükürt Sümerler tarafından bedenlerdeki böcek ve akarlara karşı kovucu olarak, MÖ 1000 yıllarında Antik Yunanistan'da ise ev ve bahçelerde böceklerin kontrolü amacı ile kullanılmıştır (MEB, 2012). MÖ 100 yıllarında çöpleme ya da boynuzotu olarak bilinen Helleborus niger, H.orientalis ve Veratrum album gibi türler kemirgenlere ve böceklere karşı, arsenik MS 900 yıllarında Çinliler tarafından yine böceklere karşı uygulanmıştır. Ağar ve ark. (1991) tarafından bildirildiğine göre, 1300 yıllarında mineral yağı develerde uyuz hastalığını önlemek için, 1649 yılında Lonchocarpus spp. (Fabaceae) ve Derris (hint sarmaşı̆̆ı) cinsine ait birkaç tropik ve subtropik bitki türünün köklerinden elde edilen rotenon balıkları yakalamak ve 1690 yılında da tütün ekstraktları temas zehiri olarak kullanılmıştır.

Pestisitler etkiledikleri canlı grubuna göre; insektisit, akarisit, mollusisit, rodentisit, avisit, afisit, fungusit, bakterisit, herbisit, algisit gibi farklı isimlerle 
tanımlanırlar ve kullanım sıklığına, miktarına, organizmaya alım şekline bağlı olarak dokularda birikebilirler (Öncüer, 1995). Bu kimyasal madde grubunun en önemli örneği, kullanımı yasaklı ya da sınırlandırılmış olan ve doğal olarak parçalanmayan organoklorlu insektisitlerdir. Böcek ilaçları olarak bilinen insektisitlerden birisi olan klordan, hidrokarbonların klorlanmasıyla elde edilmektedir. Özellikle termitlerin kontrolü ve tarımsal ürünlerin zararlılardan korunması için tarım arazilerinde uygulanmıştır. Yarı uçucu özelliğinden dolayı da atmosferde bulunabilmekte ve sudaki sedimanlara kolaylıkla bağlanabilmektedir. Bir diğer önemli özelliği de yağda çözünebilmeleri ve kolayca dokulara nüfuz edebilmeleridir (Klaassen, 1996). Topraktaki yarılanma ömrü bir yıl (IARC, 2018) olan bu madde biyolojik parçalanmalarının yavaş olması nedeni ile besin zinciri vasitasıyla canlılarda birikerek ekosistemi olumsuz şekilde etkilemekte, canlı sistemde bozulmalara, fonksiyonel aksaklıklara ve bunlara dayalı mortaliteye neden olabilmektedir (Mazet ve ark., 2005; Sevim, 2011).

Türkiye'de organoklorlu insektisitler 1945'li yıllardan itibaren kullanılmaya başlanmıştır. 1960-1970 yılları arasında çeşitli organizmalardan korunmaya yönelik olarak yaygınlaşmalarına rağmen 1983 yılından itibaren farklı alanlarda kullanımlarına büyük ölçüde yasaklar veya kısıtlamalar getirilmiştir (Çok ve ark., 1997; Erdoğrul, 2007). Bu insektisitlerden birisi olan klordan ise 1979 yılından beri aldrin ve heptaklor ile birlikte tamamen yasaklanmıştır. Ancak yapılan çeşitli çalışmalar hem yıllar önce yasaklanmış hem de günümüzde kullanılan insektisitlerin yarılanma ömürlerinin uzun olmasından dolayı çevrede hâlâ bulunabildiğini (Erinç, 1984; WHO, 2018), besin zincirinde biriktiğini, böylece hem hedef/hedef olmayan organizmalarda hem de insanlarda çeşitli toksik etkilere sebep olduğunu/olabileceğini göstermektedir (Mazet ve ark., 2005). Örneğin çeşitli araştırmacılar, diklorvos ve malationun Attagenus megatoma (halı böceği) ve Culex quinquefasciatus (sivrisinek)'da (Zettler ve Lecato, 1974; Robert ve Olson, 1989), asefat ve permetrinin Myzus persicae (yaprak biti)'da (Hsieh ve Allen, 1986), diklorvos ve azametifosun D. melanogaster'de (Çakır ve Sarıkaya, 2004), organoklorlu, organofosfatlı ve neonikotinoid gibi farklı grup insektisitlerin de yine D. melanogaster' de ömür uzunluğunu kısalttı̆̆ını ve yumurta verimini düşürdüğünü bildirmişlerdir (Uysal ve ark., 2015; Demir, 2017).Yine farklı insektisitlerin çin hamsterlerinde, ratlarda, farelerde, kromozomal aberasyonlara ve hücre döngüsü hatalarına sebep olduğu (Bagchi ve ark., 1995; Oruç ve Üner, 2000; Hazarika ve ark., 2003; Martin-Ruiz ve ark., 2004), benzeri genotoksik etkilerin insanlarda da mikronükleus yada kardeş kromatid değişimleri şeklinde gerçekleştiği gözlenmiştir (Puig ve ark., 1989; Kasimoglu ve Uysal, 2015; Kizılet ve Uysal, 2018).

Yaptığımız bu çalışmada, in vivo şartlarda kronik olarak uygulanan klordan insektisitinin hedef olmayan ve genetik çalışmalarda model bir organizma olan Drosophila melanogaster Meigen 1830 (Diptera: Drosophilidae)'in Oregon $\mathrm{R}$ yabanıl soyunda ömür uzunluğu üzerine etkileri araştırılmıştır. Ayrıca klordanın insanlarda sebep olabileceği genotoksik ve sitotoksik etkiler de insan periferal kan lenfosit hücrelerinde in vitro bir yöntem olan mikronükleus (MN) testi ile incelenmiştir.

\section{Materyal ve Metod}

\subsection{Kimyasal Maddeler}

Sigma-Aldrich şirketinden temin edilen klordan (CAS no: 12789-03-6) ömür uzunluğu ve MN testinde kullanılmak üzere \%2 dimetilsülfoksit (DMSO: CAS no:67-68-5) ile çözülmüştür. İnsektisitin yarılanma ömürüne göre hazırlanan stok çözelti belirli aralıklarla yenilenmiş ve taze hazırlanan çözelti ile deney tekrarlanmıştır. Periferik kan kültürü yönteminde kromozom medyum B (CAS no:12557013 Life tech), sitokalasin-B (CAS no:15210040 Life tech), metanol (CAS:67-56-1) ve preparatlarm boyanması için de giemsa (CAS no:109204.0500 Merck) kullanılmıştır.

\subsection{Kullanılan Organizma ve Yaşam Koşulları}

Ömür uzunluğunun belirlenmesi için çalışmalarımızın tümünde halk arasında sirke sineği/meyve sineği olarak bilinen ve genetik alanında yapılan çalışmalar için model bir organizma olan D. melanogaster'in Oregon $\mathrm{R}$ yabanıl soyu kullanılmıştır. Atatürk Üniversitesi, Fen Fakültesi, Biyoloji Bölümü Genetik Araştırma Laboratuarı'nda uzun yıllardan beri kendileştirilmiş olan bu soy, hiçbir mutant özellik bulundurmayan, uzun kanatlı, kahverengi vücutlu ve yuvarlak-kırmızı gözlüdür. Drosophila stok kültürleri, \%40-60 bağll nem, $25 \pm 1^{\circ} \mathrm{C}$ sicaklık ile sürekli karanlık koşulları taşıyan 1sıtmalı-soğutmalı sıcaklık kabinlerinde, 250mL'lik cam şişelerde yaşatılmaktadır. Hem ana stok kültürler hem de deney grupları içeriğinde toz şeker, bira mayası, agar, misır unu ve kontaminasyonu önlemek için propiyonik asit bulunan Standart Drosophila Besiyeri (SDB) ile beslenmekte ve besi yerleri yaklaşık on günde bir yenilenmektedir (Uysal ve ark., 2006).

\section{3. Ömür Uzunluğu Testinin Yapılışı}

Klordan'ın ömür uzunluğu üzerindeki etkilerinin belirlenmesi için, D. melanogaster'in Oregon $\mathrm{R}$ yabanıl soyuna ait aynı yaştaki (1-3 günlük) + ve $\delta$ popülasyonları ile ayrı ayrı çalışılmıştır. Öncelikle bu soya ait bireyler arasında çaprazlamalar yapılarak ön stoklar hazırlanmış ve pupa evresinin görüldüğü her kültür şişesindeki ebeveynler ortamdan uzaklaştırılmıştır. Pupadan çıan virgin (çiftleşmemiş) 우 ve $\widehat{0} \hat{0}$, deney gruplarında kullanılmak üzere üç gün boyunca yaklaşık dört-beş saatte bir her deneme için 100'er adet olacak şekilde toplanarak farklı kültür şişelerine alınmışlardır. Daha sonra kontrol ve deney grubu olmak üzere iki ayrı çalışma düzeneği eş zamanlı hazırlanmıştır. Kontrol grupları sadece distile su içeren $\mathrm{SDB}$ ve klordanın çözücüsü olan \%2DMSO+SDB olmak üzere iki grup olarak hazırlanmıştır. Klordan+SDB içeren deney grupları için ise önce ön denemeler yapılmış ve dört farklı uygulama dozu $(1,2,3$ ve 4 ppm) belirlenmiştir. 1ppm'den daha düşük uygulamalarda yapılmış ancak kontrol gruplarına göre herhangi bir değişim gözlenmemiştir. 4ppm'den daha yüksek uygulamalarda ise 24 saat içinde toplu ölümler görülmüştür.

Ömür uzunluğunun belirlenmesi için, kontrol ve deney gruplarına ait tüm ergin sinekler önce kültür şişelerinde 2 saat boyunca aç birakılmıştır. Daha sonra her bir uygulama için 100 birey, sayımlar sırasında kolaylık olması için 25'er bireylik dört gruba ayrılmıştır. Deney gruplarında klordan uygulaması kronik olarak yapılmış ve haftada iki kez olmak üzere farklı dozlarda klordan içeren besi yerleri yenilenmiştir. Bireyler her 
aktarımda kontrol edilmiş ve son birey ölünceye kadar sayımlar sürdürülerek ölen bireyler kaydedilmiştir. Ortam şartları hem kontrol hem de deney grupları için stabil tutulmuş, tek değişken ise SDB'ye farklı dozlarda katılan klordan olmuştur. Her bir deney serisi üç kez tekrar edilmiştir.

\subsection{Mikronükleus Testi için Donör Seçimi ve Kan Örneklerinin Alınması}

Mikronükleus çalışmaları için kan örnekleri sigara ve alkol kullanmayan, yakın zamanda enfeksiyon geçirmemiş, $X$ ışını gibi herhangi bir fiziksel ajana maruz kalmamış, 23-25 yaşlarında sağlıklı üç farklı bireyden alınmıştır. Bu çalışmanın etik kurul izni Erzurum Bölge Eğitim ve Araştırma Hastanesi "Klinik Araştırma Etik Kurulu" tarafından verilmiştir (Sayı: 37732058-53/2467, Karar no: BEAH KAEK 2015/9-67).

\subsection{Mikronüklus Testinin Yapılışı}

İnsan periferal lenfositlerinde klordana bağlı mikronükleus frekansının belirlenmesi için Fenech (2000) ile Kirsch-Volders ve ark. (1997) tarafından geliştirilen yöntem modifiye edilerek kullanılmıştır. Bu amaçla sağlıklı üç ayrı bireyden alınan 0,25 ml kan numunesi, 5 $\mathrm{ml}$ hazır besi yerine (kromozom medyum B) eklenmiş ve $37^{\circ} \mathrm{C}^{\prime}$ de inkübasyona bırakılmıştır. İnkübasyonun 24.saatinde ön denemelerle belirlenen klordanın dört farklı dozu (30, 40, 50 ve 60 ppm) hücre kültür tüplerine ayrı ayrı eklenmiştir. 48. saatte ise sitokinezi engellemek için her tüpe son konsantrasyonu $3 \mu \mathrm{g} / \mathrm{mL}$ olacak şekilde sitokalasin-B ilave edilmiştir. 72. saatte tüpler santrifüj edilerek (1000 rpm) süpernatant atılmış yerine hipotonik solüsyon eklenmiştir. $37^{\circ} \mathrm{C}^{\prime}$ de beş dakika bekletilen tüpler tekrar santrifüj edilerek pellet kısmı tespit çözeltisi ile fiske edilmiştir. Son santrifüj işleminden sonra kalan pelletten yayma preparatlar hazırlanmış ve giemsa ile boyanmıştır. Hazırlanan preparatlar 1şık mikroskobunda (10x40) incelenmiş ve MN sayımı Countryman ve Heddle (1976) tarafından belirlenen kriterlere göre binükleat hücrelerinde $(\mathrm{BNH})$ yapılmıştır. Ayrıca klordanın sitotoksik etkisinin belirlenmesi için rastgele 1000 hücre sayılarak nükleer bölünme indeksi de (NBI) hesaplanmıştır. Deney gruplarına ait sonuçlar, distile su ve klordanın çözücüsü olan \%2'lik DMSO negatif kontrol grupları ve mutajenik etkisi iyi bilinen etilmetansülfonat (EMS) pozitif kontrol grubu ile karşılaştırılmıştır.

\section{6. İstatistik Yöntemler}

Ömür uzunluğu ve mikronükleus çalışmalarından elde edilen sonuçların istatistiksel analizleri için SPSS 13.0 (Statistical Package for the Social Sciences) program1 kullanılmıştır. Grupların normal dağılım gösterip göstermediği Kolmogorov-Smirnov testi ile doğrulanmıştır. Grupların homojenliği de Levene testi ile değerlendirilmiştir. $\mathrm{MN}$ ve NBI'ye ait veriler tek değişkenli varyans analizi (ANOVA) ve Tukey testi ile kontrol ve deney gruplarına ait ömür uzunluğu ortalama değerleri ise \%5 düzeyinde Duncan testi ve korelasyon analizi ile karşılaştırılmıştır.

\section{Sonuçlar}

\section{1 İn vivo Ömür Uzunluğu Testi}

D. melanogaster' in + ve $\widehat{o}$ popülasyonlarına ait maksimum

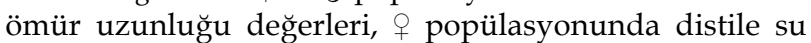
kontrol (1) ve DMSO kontrol grupları için (2) sırasıyla 78 ve 74 gün, ô popülasyonunda ise 76 ve 74 gün olarak bulunmuştur (Tablo 1). Her iki popülasyonun kontrol grupları arasında maksimum ömür uzunluğu bakımından istatistiki olarak fark yoktur $(\mathrm{P}>0,05)$. Ancak artan klordan konsantrasyonuna bağlı olarak her iki popülasyonda maksimum ömür uzunluğunun gerilediği saptanmıştır.

Tablo 1. Kronik klordan uygulanmış $D$. melanogaster'in $\uparrow$ ve ồ popülasyonlarında maksimum ve ortalama ömür uzunluğunun karşılaştırılması

KLORDAN

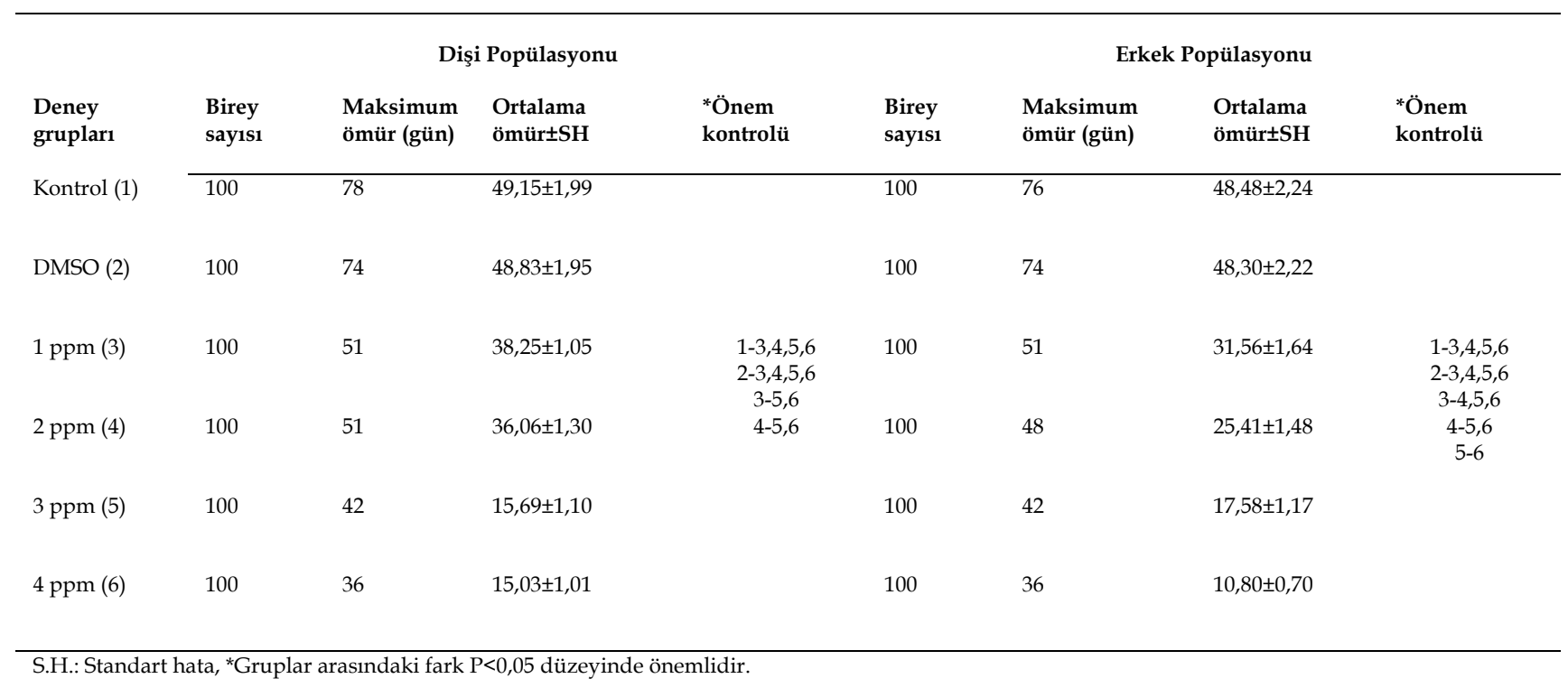


Söyle ki; DMSO kontrol grubunda her iki popülasyon için 74 gün olan maksimum ömür uzunluğu, hem + hem de $\delta$ popülasyonunda en düşük ve en yüksek uygulama gruplarında (1-4 ppm) sirasiyla 51 ve 36 gün olarak bulunmuştur. $\mathrm{Bu}$ gerileme istatistiki olarak $\mathrm{P}<0,05$ düzeyinde önemlidir.

Sunulan çalışmada klordan uygulamasına bağlı olarak maksimum ömür uzunluğunun yanı sıra ortalama ömür uzunluğu da belirlenmiştir (Tablo 1). Bu değerler + popülasyonu için distile su kontrol (1) ve DMSO kontrol grubunda (2) sirasiyla $49,15 \pm 1,99$ ve $48,83 \pm 1,95$ gün, ô popülasyonunda ise $48,48 \pm 2,24,48,30 \pm 2,22$ gündür. Her iki kontrol grubu arasındaki fark $\phi$ ve $\hat{\jmath}$ popülasyonları için önemsiz bulunmuştur $(\mathrm{P}>0,05)$. Ancak o popülasyonunun DMSO kontrol grubunda 48,83 $\pm 1,95$ gün olan maksimum ömür uzunluğu en düşük ve en yüksek uygulama gruplarında (1-4ppm) 38,25 $\pm 1,05$ günden $15,03 \pm 1,01$ güne gerilemiştir $(\mathrm{P}<0,05)$. $\widehat{o}$ popülasyonunda da 48,30 $\pm 2,22$ gün olan DMSO kontrol grubuna ait maksimum ömür uzunluğu değeri, 1ppm

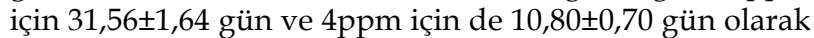
belirlenmiştir $(\mathrm{P}<0,05)$. Doz artışı ve maksimum ömür uzunluğu arasında gözlenen bu negatif korelasyona ait değerler de of için R:-660 ve ổ $\widehat{o}$ için de R:-639 olarak hesaplanmiştır.

Kontrol ve deney gruplarına ait maksimum ömür uzunluğu değerlerine göre $q$ ve $\hat{\jmath}$ popülasyonları için hayatta kalış eğrileri de çizilmiştir (Şekil 1 ve Şekil 2).

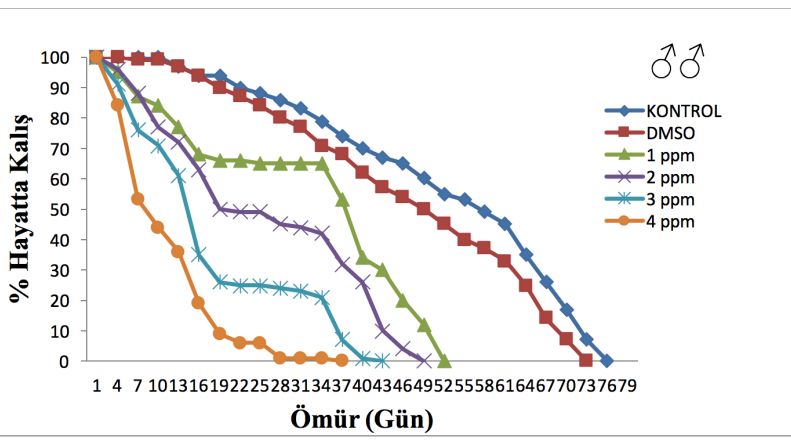

Şekil 1. Klordan uygulanmış ô popülasyonu için hayatta kalış eğrisi.

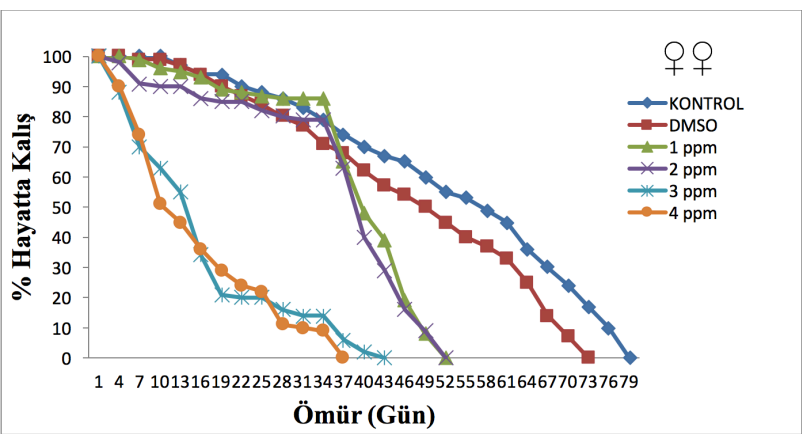

Şekil 2. Klordan uygulanmış + popülasyonu için hayatta kalış eğrisi.

\section{2 İn vitro Mikronükleus Testi}

Klordan uygulaması ile insan periferal lenfositlerinde oluşan mikronükleus frekansına ait değerler, negatif ve pozitif kontrol grupları ile karşılaştırılmıştır. Bu değerler

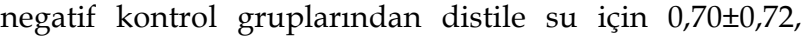
DMSO için $0,83 \pm 0,70$ iken EMS pozitif kontrol grubunda $5,73 \pm 0,90$ olarak bulunmuştur (Tablo 2). Distile su ve DMSO negatif kontrol grubu arasındaki fark istatistiki olarak $\mathrm{P}>0,05$ düzeyinde önemsizken pozitif kontrol olan EMS ile her iki negatif kontrol grubu arasındaki fark önemlidir $(\mathrm{P}<0,05)$.

En düşük (30ppm) ve en yüksek (60ppm) klordan uygulaması sonucu elde edilen $\mathrm{MN}$ frekansina ait değerler ise sirasiyla $0,77 \pm 0,40$ ve $5,10 \pm 0,12$ olarak hesaplanmıştır. Tablo 2'de de görüldüğü gibi $M N$ frekansı bakımından en düşük uygulama grubu (30ppm) ile kontrol grupları arasındaki fark önemsizken $(P>0,05)$ doz artışına bağlı olarak MN frekansında gözlenen artış (P<0,05, F:24,295, df:27) genotoksisitenin uyarıldığını göstermektedir.

$\mathrm{Bu}$ çalışmada kronik klordan uygulamasına bağlı olarak sitotoksik etkinin göstergesi olan NBİ değerleri de hesaplanmıştır. Distile su ve DMSO negatif kontrol grupları için sırasıyla $1,52 \pm 0,20$ ve $1,54 \pm 0,40(\mathrm{P}>0,05)$ olan NBİ, EMS pozitif kontrol için $1,29 \pm 0,30^{\prime}$ dur $(\mathrm{P}<0,05)$.En düşük ve en yüksek klordan uygulama gruplarında (30$60 \mathrm{ppm})$ ise yine sirasiyla $1,24 \pm 0,11$ ve $1,21 \pm 0,51$ olan NBI'nin DMSO kontrol grubuna göre azaldığ 1 ve bu azalışın da istatistiki olarak önemli olduğu $(\mathrm{P}<0,05)$ Tablo 2 'de görülmektedir.

Tablo 2. Klordan uygulaması ile periferal lenfosit hücrelerinde oluşan MN ve NBİ değerleri:

\begin{tabular}{|c|c|c|c|c|c|c|c|}
\hline \multirow{2}{*}{$\begin{array}{l}\text { Uygulama } \\
\text { grupları }\end{array}$} & \multirow[t]{2}{*}{ Uygulama dozu } & \multirow{2}{*}{$\begin{array}{c}\text { İncelenen BNH } \\
\text { sayısı }\end{array}$} & \multicolumn{3}{|c|}{ BNH içindeki MN } & \multirow[t]{2}{*}{$\% \mathrm{MN}$} & \multirow{2}{*}{$\begin{array}{c}\text { Nükleer bölünme } \\
\text { indeksi }\end{array}$} \\
\hline & & & 1'li & 2'li & 3'lü & & \\
\hline Distile su & - & 3000 & 21 & - & - & $0,70 \pm 0,72^{\mathrm{a}}$ & $1,52 \pm 0,20^{\mathrm{a}}$ \\
\hline DMSO & $\% 2$ & 3000 & 25 & - & - & $0,83 \pm 0,70^{\mathrm{a}}$ & $1,54 \pm 0,40^{\mathrm{a}}$ \\
\hline \multirow{4}{*}{$\begin{array}{c}\text { Klordan } \\
\text { (ppm) }\end{array}$} & 30 & 3000 & 23 & - & - & $0,77 \pm 0,40^{\mathrm{a}}$ & $1,24 \pm 0,11^{b}$ \\
\hline & 40 & 3000 & 47 & 3 & - & $1,77 \pm 0,90^{\mathrm{b}}$ & $1,25 \pm 0,15^{\mathrm{b}}$ \\
\hline & 50 & 3000 & 70 & 10 & - & $3,00 \pm 0,18^{\mathrm{c}}$ & $1,23 \pm 0,45^{\mathrm{b}}$ \\
\hline & 60 & 3000 & 78 & 24 & 9 & $5,10 \pm 0,12^{\mathrm{d}}$ & $1,21 \pm 0,51^{\mathrm{b}}$ \\
\hline EMS & $10 \mathrm{mM}$ & 3000 & 108 & 17 & 10 & $5,73 \pm 0,90^{\mathrm{d}}$ & $1,29 \pm 0,30^{\mathbf{b}}$ \\
\hline
\end{tabular}




\section{Tartışma}

Tüm canlılar ekosistem içinde birlikte yaşamaktadır. İnsanoğlunun yaşamı bitkilerin ve hayvanların varlığına, bunların bulunduğu ortama ve yaşadıkları yere bağlıdır. Yaşam için gerekli olan ihtiyaçlarımızın karşılanması için de canlı çeşitliliğine ihtiyaç duyulmaktadır. Ancak yine bizlerden kaynaklanan örneğin çeşitli kirleticiler vasitasıyla doğada meydana gelen tahribatlar, yangınlar, bunlara bağlı iklim değişiklikleri, ekilebilir alanların yok edilmesi vs. gibi sebeplerle zengin canlı çeşitliliği giderek kaybolmaktadır. Dolayısıyla yaşam alanlarında meydana gelen bu gibi değişiklikler, zengin canlı çeşitliliği için gerçek birer risk faktörüdür. Bugün dünyamızda var olan biyoçeşitlilik, dört milyar yıllık evrilmenin sonucu olarak milyonlarca biyolojik türü içermekte fakat her geçen gün giderek artan hızla da farklı türler ve onlara ait yaşam alanları yok olmaktadır. Uzman görüşlerine göre; günümüzde tür kayıplarının hızı, doğal kayıp hızından 1000-10.000 kat yüksektir ve her yıl var olan türlerin \%0,01-0,1 oranında soyu tükenmektedir (WWF, 2018).

Biyoçeşitlilikte rakamlarla ifade edilen bu erozyonun sebeplerinden birisi de kimyasal kirleticilerden pestisitlerdir. Farklı çeşitleri olan pestisitlere ve özellikle insektisitlere bağlı olarak ekolojik denge geri dönüşümsüz olarak bozulmaktadır. Çünkü bu kimyasal maddeler hem biyoçeşitlilikte azalmaya hem de yaşayan türlerin ömür uzunluğunda kısalmaya sebep olmaktadır/olabilmektedir. Ünlü ve Bozcuk (1979)'a göre, Drosophila' da ömür uzunluğu, farklı türlerde, aynı türün farklı eşeylerinde ve mutant türler arasında farklılık gösterdiği gibi aynı genotipe sahip popülasyonlar farklı çevresel koşullarda farklı ömür uzunluklarına sahip olabilirler. Ömür uzunluğu kantitatif bir karakter olmasına rağmen genler ve çevresel faktörler arasındaki etkileşim ile de bu süre değişebilmektedir (Kızılet ve Uysal, 2012)

Klordan kontakt etkili bir insektisit olup yarı uçucu özelliğinden dolayı uygulamadan sonra da atmosferde bulunabilmekte ve gerek solunum yoluyla gerekse deriden difüze olarak canlıları etkileyebilmektedir. Sudaki sedimanlara kolaylıkla bağlanabildiğinden akuatik canlıların yağ dokularına biyokonsantre olabilmektedir (Sevim, 2011). Özellikle kronik zehirlenmelerde karaciğer mikrozomal enzim sistemlerini de inhibe etmektedirler. Topraktaki yarılanma ömrü yaklaşık 1 yıl olan klordan, tüm bu özelliklerinden dolayı Uluslararası Kanser Araştırmaları Ajansı (IARC, 2018) tarafından 2B grubu yani insanlarda karsinojenik olarak sınıflandırılmıştır. Günümüzde bunun gibi pek çok tarım ilacının kullanımı çeşitli ülkeler tarafından yasaklanmış veya kısıtlanmıştır. Ancak kalıntılarına toprakta ya da farklı organizmalarda hala hem ülkemizde (Özgün ve ark., 1997; Ağca, 2006; Yavuz, 2007; Dağl1, 2008) hem de farklı ülkelerde (Torreti, 1987; Prasad ve Chhabra, 2001; Garrido-Frenich ve ark., 2003) rastlanılabilmektedir. T1pk1 klordan gibi organoklorlu olan DDT ve toksafen gibi bazı pestisitlerin kullanımı uzun süreden beri yasaklı olmasına rağmen, kutupların yüksek kısımları gibi yeryüzünün en ücra bölgelerinde bile bulunabilmektedir. $\mathrm{Bu}$ durum da pestisitlerin global hava sirkülasyonuyla taşındığını göstermektedir (Harris, 2000; Mahmoud ve Loutfy, 2012).

$\mathrm{Bu}$ çalışmadan elde edilen sonuçlara göre kronik klordan muamelesi hedef olmayan organizmalardan $D$. melanogaster'in $q$ ve ồ bireylerinde hem ortalama hem de maksimum ömür uzunluğunu çok belirgin şekilde kısaltmış ve bu durum popülasyon yaşlanmasına sebep olmuştur. Daha önce farklı organizmalar ile yapılan az sayıdaki çalışmaların sonuçları bizim bulgularımızla paralellik göstermektedir. Şöyle ki; kronik klordan uygulamasiyla Ceriodaphnia dubia ve Daphnia manga (Cladocera:Daphniidae) gibi akuatik ve hedef olmayan türlerde de hayatta kalış oranlarının önemli ölçüde azaldığ 1 (Manar ve ark., 2012), 5,3 ve 11,5 g/ L klordanın Hyalella azteca (amfipod)'da büyüme ve hayatta kalış1 inhibe ettiği (Cardwell ve ark., 1977) neonikotinoidlerin de bu türlü etkiye sahip olduğu gözlenmiştir (Uysal ve ark., 2015). Çakır ve Sarıkaya (2004)'ya göre, organofosfatlı insektisitlerden metil paration, diazinon ve diklorvos'ta tıpkı klordan gibi D. melanogaster'in yaşama yüzdesini azaltmiştır. Muscidifurax raptor (Hymenoptera)'un ömür uzunluğu da azadiraktine bağlı olarak erkek bireylerde \%25,1, dişi bireylerde de \%15,7 oranında kısalmıştır (Ruiu ve ark., 2008). Klordan gibi kirleticiler vücudun antioksidan savunması ile hücrelerin lipid tabakasının peroksidasyonuna neden olan serbest radikal üretimi arasında dengesizliğe sebep olarak oksidatif strese yol açarlar. Yapılan bu çalışmada da olduğu gibi insektisitlerin etkisiyle hücrede oksidan ve antioksidan sistem arasındaki denge bozulduğunda serbest radikaller çoğalmakta bu da oksidatif strese, membran akıcılığında değişikliğe, DNA hasarına ve karsinojenik etkiye sebep olmaktadır (Bagchi ve ark., 1995; Oruç ve Üner, 2000; Hazarika ve ark., 2003). DNA hasarı ve oksidatif stres ise çeşitli hastalıkları, patolojik durumları ve telomer kısalmalarını tetikleyerek yaşlanmayı hızlandırmaktadır (Martin-Ruiz ve ark., 2004; Soltani ve ark., 2009). Bu çalışmada D. melanogaster'in yaşamı bakımından gerekli olan tüm iç ve dış faktörler stabil tutulmuştur. Tek değişken $\mathrm{SDB}^{\prime}$ ye farklı dozlarda ilave edilen klordan insektisitidir ve "bu kimyasal maddenin tüm uygulama gruplarında ömür uzunluğunu sinırlandırarak popülasyon yaşlanmasına sebep olduğu" sonucuna varabiliriz.

Ayrıca klordanın tüm tarımsal ürünlerde, özellikle çay, yağlı tohum ve meyvelerde kalıntı bıraktığı belirlenmiştir. Buna bağlı olarak doğrudan (hava, su ve değme etkisi ile) ya da dolaylı olarak (besin zinciri yoluyla) üç ile on beş ay arasında klordana maruz kalan insanlar üzerinde yapılan bir araştırmada immün sistemin hasar gördüğü tespit edilmiştir (MEB, 2012). İmmün yetmezliğe bağlı sistemik hastalıklar ise ömür uzunluğunu sınırlandırıcı bir diğer faktör olarak ele alınmaktadır.

Bu çalışmada klordanın etkileri in vitro şartlarda da incelenmiştir. İnsan lenfosit hücrelerine farklı dozlarda yapılan uygulamalarda doz artışına bağlı olarak MN frekansının arttığı ve bu böcek ilacının insanlarda genotoksik etkili olduğu belirlenmiştir. Ayrıca NBI'yi düşürerek sitotoksik etkiyi de uyarmıştır. Daha önce yapılan çeşitli çalışmalarda farklı insektisitlerin de (Kasımoğlu ve Uysal, 2016) genotoksik ajan olduğu belirlenmiştir. Kızılet ve Uysal (2017)'a göre neonikotinoid insektisitler hem MN hem de kardeş kromatit değişimini (KKD) artırarak genotoksisiteye ve somatik mutasyonlara sebep olmaktadır. Aldrin, dieldrin ve heptaklor ile benzer işleve sahip olan klordan, GABA ( $\gamma$-aminobütirik asit) reseptör-klor kanal kompleksini etkileyerek nörotoksik özelliği ile sinir-kas kavşaklarında ve endokrin sinyallerde olumsuzluklara neden 
olmaktadır (Walker ve ark., 2006). Ayrıca hücre içinde $\mathrm{Ca}^{+2}$ iyon derişimini etkilemekte ve bu değişim de hücre içinde $\mathrm{Ca}^{+2}$ bağlı proteaz ve nükleaz enzimlerinin aktivitelerini artırarak serbest radikal uyarımını tetiklemektedir. Fenech ve ark. (2003)'a göre, DNA'da meydana gelebilecek zincir kırıkları da mikronükleus oluşumuna neden olmaktadır.

Sunulan bu çalışmanın sonuçlarında da görüldüğü gibi klordanın ya da farklı insektisitlerin kullanımına bağlı genotoksisite sebebiyle baş gösteren genomik kusurların (Kasimoglu ve Uysal, 2015) nesiller boyu sürekliliği, bu maddelerin yarılanma ömürlerinin uzun olmasından, organizmanın dokularında birikmesinden ve besin zinciri yoluyla çok farklı habitatlara taşınarak farklı canlı gruplarını etkilemesinden kaynaklanmaktadır. Bu sebeple zirai mücadele amacıyla pestisit kullanımı insana, çevreye, gıda güvenliğine ve doğal dengeye olumsuz etkileri en aza indirilecek şekilde teknik talimatlara, gereken dozlara ve bitki büyümesine uygun olarak yapılmalıdır. $\mathrm{Bu}$ bağlamda yapılacak yanlış bir uygulamanın insanlara, hayvanlara, bitkilere ve çevreye telafi edilemez zararlar verebileceği de asla unutulmamalıdır.

\section{Kaynaklar}

Ağar, S., Aydınoğlu, H., \& Ece, H. (1991). Pestisit kullanımının tarihçesi, bugünü ve geleceği. Türk Entomoloji Dergisi, 15(4), 247-56.

Ağca, İ. (2006). Konya'da satılan bazı balık türlerinde organoklorlu bazı pestisit kalıntılarının tayini (Yüksek Lisans Tezi). Selçuk Üniversitesi, Konya, Türkiye.

Bagchi, D., Bagchi, M., \& Stohs, S.J. (1995). In vitro and in vivo generation of reactive oxygen species, DNA damage and lactate dehydrogenase leakage by selected pesticides. Toxicology, 104(1,3), 129-140.

Cardwell, R.D., Foreman, D.G., Payne, T.R., \& Wilbur, D.J. (1977). Acute and chronic toxicity of chlordane to fish and invertebrates. EPA 600/377-019. Duluth, MN, USA, Environmental Protection Agency, 138pp.

Countryman, R.I., \& Heddle, J.A. (1976). The production of micronuclei from chromosome aberration in irradicated cultures of human lymphocytes. Mutatian Research, 41, 321-332.

Çakır, Ş., \& Sarıkaya, R. (2004). Bazı organik fosforlu insektisitlerin Drosophila melanogaster'in yaşama yüzdesi üzerine etkisi. Gazi Üniversitesi, Gazi Ĕgitim Fakültesi Dergisi, 24(3), 71-80.

Çok. I., Bilgili, A., M., Özbek, H., Bilgili, N., \& Burgaz, S. (1997). Organochlorine pesticide residues in human breast milk from agricultural regions of Turkey, 1995-1996. Bulletin of Environmental Contamination and Toxicology, 59, 577-582.

Dağlı, Z. (2008). Konya bölgesindeki budaylarda organik klorlu pestisit seviyelerinin araştırılması (Yüksek Lisans Tezi). Selçuk Üniversitesi, Konya, Türkiye.

Demir, B. (2017). Drosophila melanogaster'in yabanıl ve mutant türlerinde insektisitlerin in vivo ömür uzunluğu üzerine etkilerinin karşılaştırlması (Yüksek Lisans Tezi). Atatürk Üniversitesi, Erzurum, Türkiye.

Erdogrul, O. (2007). Levels of selected pesticides in honey samples from Kahramanmaraş, Turkey. Food Control, 18, 866-871.

Erinç, S. (1984). Ortam Ekolojisi ve Degredasyonal Ekosistem Değisiklikleri, İstanbul, Türkiye, İstanbul Üniversitesi Deniz Bilimleri ve Coğrafya Enstitüsü Yayınları, 144pp.

Fenech, M. (2000). The in vitro micronucleus technique. Mutatian Research, $455(1,2), 81-95$

Fenech, M., Chang, W.P., \& Zeiger, E. (2003). HUMN project: detailed description of the scoring criteria for the cytokinesis-block micronucleus assay using isolated human lymphocyte cultures. Mutation Research - Genetic Toxicology and Environmental Mutagenesis, $534,65-75$.

Garrido-Frenich, A. Arrebola, F.J., Gonzales M. Vidal, J.L. \& Diez, N.M. (2003). Rapid pesticide analysis in post harvest plants used as animal feed by low pressure gas chromatography-tandem mass spectrometry, Analytical and Bioanalytical Chemistry, 377(6),1038-46.
Güler Ç., \& Çobanoğlu Z. (1997). Pestisitler. Ankara, Türkiye, Çevre Sağlığı Temel Kaynak Dizisi No:52, 173 pp.

Harris J. (2000) Chemical pesticide markets, health risks and residues, New York, USA, CABI publishing, 90pp. 0851994768.

Hazarika, A., Sarkar, S.N., \& Malik, J.K. (2003). Influence of malathion pretreatment an the toxicity of anilofos in male rats: a biochemical interaction study. Toxicology, 185, 1-8.

Hsieh, C.Y., \& Allen, W.W. (1986). Effects of insecticides on emergence, survival, longevity and fecundity of the parasitoid Diaeretiella rapae (Hymenoptera: Aphidiidae) from mumified Myzus persicae (Homoptera:Aphididae). Journal of Economic Entomology, 79, 1599-1602.

Kasımoğlu, C., \& Uysal, H. (2016). Genoprotective effects of aqueous extracts of Rosa canina L. fruits on ethylmethanesulfonate induced DNA damage in Drosophila melanogaster. Cumhuriyet Science Journal, 3, 1300-1949.

Kasimoglu, C., \& Uysal, H. (2015). Mutagenic biomonitoring of pirethroid insecticides in human lymphocyte cultures: Use of micronuclei as biomarkers and recovery by Rosa canina extracts of mutagenic effects. Pharmaceutical Biology, 53, 625-629.

Kızılet H., \& Uysal H. (2017). Macro and micro genetic damage induced by the neonicotinoids, Arapgirlioglu H., Atik A., Elliot L., Turgeon E., (Eds). Researcher on Science and Art in 21st Century Turkey, Chapter 149, Ankara, Türkiye, Gece Kitaplığı Yayınevi., 1313-1321 pp.

Kızılet H., \& Uysal H. (2018). Neonikotinoidler ile İnsan Lenfositlerinde Genotoksisitenin Uyarılması. Cumhuriyet Science Journal, 39(1), 201-210.

Kızılet, H., \& Uysal, H. (2012). Ergin Drosophila'nın ömür uzunluğunda kronik zearelenon alımına bağlı olarak toksisitenin uyarılması. Atatürk Üniversitesi Ziraat Fakültesi Dergisi, 43(1), 1-5.

Kirsch-Volders, M., Elhajouji, A., \& Van Hummelen, P. (1997). The in vitro micronucleus test: a multi-endpoint assay to detect simultaneously mitoticdelay, apoptosis, chromosome breakage, chromosome loss and non-disjunction. Mutation Research, 392(1), 19-30.

Klaassen, C.D. (1996). Casarett \& Doull's Toxicology: The Basic Science of Poisons, 7th ed. New York, USA, Mc Graw-Hill Medical Publishing Division., 1309 pp.

Mahmoud F.M., \& Loutfy N. (2012) Biocides. In: Rathore, H. S., Nollet, L. M. L. (ed.), Pesticides evaluation of environmental pollution, Section 1 CRC Press, Boca Raton, USA, pp. 14

Manar, R., Vasseur, P., \& Bessi, H. (2012). Chronictoxicity of chlordane to Daphnia manga and Ceriodaphnia dubia: A comparative study. Environmental Toxicology, 27(2), 90-97.

Martin-Ruiz, C., Saretzki, G., Petrie, J., Ladhoff, J., Jeyapalan, J., Wei, W., Sedivy, J., \& Von Zglinicki, T. (2004). Stochastic variation in telomere shortening rate causes heterogeneity of human fibroblast replicative life span. The Journal of Biological Chemistry, 279(17), 17826-17833.

Mazet, A., Keck, G., \& Berny, P. (2005). Concentrations of PCbs, organochlorine pesticides and heavy metals (lead, cadmium and copper) in fish from the Drome river: Potential effects on otters (Lutra lutra). Chemosphere, 61(6), 810-816.

Oruç, E.Ö., \& Üner, N. (2000). Combined effects of 2,4-d and azinphosmethyl on antioxidant enzymes and lipid peroxidation in liver of Orochromis niloticus. Comparative Biochemistry and Physiology, 127, 291-296.

Öncüer, C. (1995). Tarımsal Zararlılarla Savaş Yöntemleri ve İlaçları. İzmir, Türkiye, Ege Üniversitesi Basımevi., 333 pp.

Özgün, O., Boncuk, H., Sarıuül, A., Atamar, P., Yüksel, L., Salcı, B., \& Şenöz, B. (1997). "Meyve sularında bazı pestisit kalıntıları üzerine araştırmalar", TAGEM İl Kontrol Lab. Müd., Ankara, Genel yay., No: 35, Özel yay no: 31, 25pp.

Prasad, K., \& Chhrabra, A. (2001). Pesticide residües in animal feeds and fodders. Indian Journal of Animal Sciences, 71(12), 1178-1180.

Puig, M., Carbonel, E., Xamena, N., Creus, A., \& Marcos, R. (1989). Analysis of cytogenetic damage induced in cultured human lymphocytes by the pyrethroid insecticides cypermethrin and fenvalerate. Mutagenesis, 4, 72-74.

Robert, L.L., \& Olson, J.K. (1989). Effect of sublethal dosages of insecticides on Culex quinquefasciatus. Journal of the American Mosquito Control Association, 5 (2), 239-46.

Ruiu, L., Satta, A., \& Floris, I. (2008). Effects of an azadirachtin-based formulation on the non-target muscoid fly parasitoid Muscidifurax raptor (Hymeneoptera: Pteromalidae). Biological Control, 47, 66-70. 
Sevim, R. (2011). Toksikoloji Pestisitler. Antalya, Türkiye, Akdeniz Üniversitesi yayınları., $17 \mathrm{pp}$.

Soltani, F., Mosaffa, F., \& Behravan, J. (2009). Evaluation of antigenotoxicity effects of umbelliprenin on human peripheral lymphocytes exposed to oxidative stress. Cell Biology and Toxicology, 25, 291-296.

T.C. Millî Eğitim Bakanlığı (MEB) (2012). Çevre Sağlı̆̆ı Pestisitler, Ankara, Türkiye, $54 \mathrm{pp}$.

Torreti, L. 1987. Rapid determination of organochlorine pesticide residues in feeds by capillary gas chromatography, Journal of High Resolution Chromotography \& Chromotography Communications, 10: 510-515.

Uluslararası Kanser Araştırmaları Ajansı (IARC-The International AgencyforResearchonCancer) Retrieved from https://www.iarc.fr/ and

https://webdosya.csb.gov.tr/db/kimyasallar/editordosya/Klordan(2 ) .pdf

Uysal, H., Şişman, T., \& Aşkın, H. (2006). Drosophila Biyolojisi ve Çaprazlama Yöntemleri. Erzurum, Türkiye, Atatürk Üniversitesi Yayınları, 53 pp. ISBN:975-442-111-0

Uysal, H., Ünver, S., \& Kizılet, H. (2015). The effects of neonicotinoids on the longevity in male and female populations of D. melanogaster (fruit fly). Ekoloji, 24(96), 57-63.

Ünlü, H., \& Bozcuk, A.N. (1979). Genetics of longevity in Drosophila I: The Effects of $\mathrm{w}, \mathrm{m}$ and $\mathrm{f}$ mutant genes in various genotype combinations. Experimental Gerontology, 14, 117-124.

Walker, C.H., Hopkin, S.P., Sibly, R.M., \& Peakall, D.B. (2006). Principles of Ecotoxicology. FL, USA. CRC pres., 386 pp.

World Health Organization (WHO) Guidelines on public health pesticide management policy. Retrieved from http://www.who.int/whopes/resources/SEA_CD_214.pdf

World Wildlife Fund (WWF) Turkey/Dünya Doğayı Koruma Vakfı Türkiye $\quad$ Retrieved from http://www.turkiyenincani.org/turkiyenincani/

Yavuz, H. (2007). Konya'da satılan ballardaki bazı pestisid residülerinin belirlenmesi (Yüksek Lisans Tezi). Selçuk Üniversitesi, Konya, Türkiye.

Zettler, J.L., \& Lecato, G.L. (1974). Sublethal doses of malathion and dichlorvos: effects of fecundity of the black carbet betle. Journal of Economic Entomology, 67(1), 19-21. 